\title{
DAYA HAMBAT EKSTRAK KULIT JATI (Tectona grandis Linn F) TERHADAP PERTUMBUHAN JAMUR PELAPUK KAYU Schizophyllum commune Fries
}

\author{
(Inhibition of Teak bark (Tectona grandis Linn F) extract against the growth of wood decay \\ fungi Schizophyllum commune Fries)
}

\author{
Ferry Vernando Hutabarat, Farah Diba, Lolyta Sisilia \\ Fakultas Kehutanan Universitas Tanjungpura Jl. Daya Nasional, Pontianak 78124 \\ Email: ferryvernando@gmail.com
}

\begin{abstract}
The aim of the research was to examine the antifungal activity and the most effective concentration of teak bark (Tectona grandis Linn F) extract in inhibiting wood decay fungi Schizophyllum commune Fries. Teak bark was derived from BKPH Ledok, Sambong district, Blora Regency, West Java. The Teak bark made into particle with size pass of 40 mesh and retained 60 mesh. Then one kilogram of teak bark particle was maceration with 10 liter of aquadest. The extract then mixes with potatoes dextrose agar (PDA) with several concentration i.e. $0 \%, 0.25 \%, 0.5 \%, 0.75 \%$ and $1 \%$ and pour into petri dish. One isolate of Schizophyllum commune was put in the center of PDA in each petri dish then incubated for nine days. The bioactive compound of extract teak bark was evaluation used phytochemical screening. Result of the research showed that teak bark extract at concentration $0.25 \%$ and $0.5 \%$ has antifungal activity values was $27.98 \%$ and $40.38 \%$ and categorized as medium inhibition growth of $S$. commune. Meanwhile at concentration $0.75 \%$ and $1 \%$ the AFA values was $59.94 \%$ and $65.51 \%$ categorized as strong inhibition growth of $S$. commune. The bioactive compounds from phytochemical screening test were alkaloid, flavonoid, terpenoid, fenolik, antrakuinon, and saponin. The extract of teak bark with concentration $0.75 \%$ and $1 \%$ are the most effective concentrations in inhibiting the growth of wood decay fungi S. commune Fries.
\end{abstract}

Keywords : antifungal, phytochemical screening test, Schizophyllum commune, Tectona grandis

\section{PENDAHULUAN}

Sampai saat ini kayu masih memegang peranan penting dalam kehidupan manusia. Kemudahan kayu untuk dapat diperoleh dalam berbagai bentuk dan ukuran, disertai sifatsifatnya menjadikan kayu itu sebagai salah satu bahan bangunan yang diminati dari dulu sampai sekarang. Ketersediaan kayu di hutan tropis Indonesia terutama kayu kelas awet I dan kelas awet II semakin terbatas, sehingga masyarakat beralih menggunakan kayu kelas awet III dan kelas awet IV yang mempunyai keawetan alami rendah. Kayu yang memiliki kelas awet rendah mudah rusak dan lapuk jika dipakai atau dipasang di tempat terbuka tanpa naungan, terutama jika berhubungan dengan tanah lembab, sebab pada dasarnya kayu tidak tahan terhadap perubahan suhu, udara, kelembaban, dan air (Barly, 2012). Kayu-kayu yang kurang awet ini rentan ketahanannya terhadap faktor perusak kayu terutama faktor biologis seperti jamur, bakteri, serangga, dan binatang laut (marine borer). Serangan jamur pada kayu adalah salah satu faktor biologis 
perusak yang harus dikendalikan (Barly dan Sabarudi, 2010).

Jamur $S$. commune merupakan salah satu jamur jamur pelapuk kayu yang menyebabkan kerusakan kayu terparah. Jamur S. commune merupakan jamur pelapuk putih (white rot) dan termasuk ke dalam famili Agaricaceae (Oramahi et al. 2012). Jamur $S$. commune merupakan salah satu jenis jamur pelapuk kayu yang sangat potensial dan dapat tumbuh secara alami pada batang pohon maupun pada limbah kayu hasil hutan (Herliyana et al. 2011). Menurut SNI 01-7207-2006, terdapat tiga jenis jamur pelapuk kayu yang memiliki daya serang (virulensi) tinggi dan banyak ditemukan di Indonesia, yaitu Shizophyllum commune Fries, Pycnoporus sanguineus Fries Korst, dan Dacryopinax spathularia Sch. Jamur S. commune mempunyai pertumbuhan yang relatif mudah dan cepat selain itu jamur ini juga merupakan jamur pelapuk kayu yang cukup ganas karena dalam beberapa kasus dapat menyebabkan kehilangan berat sampai $30 \%$ (Herliyana et al. 2011).

Penggunaan kayu-kayu awet sampai saat ini belum memecahkan masalah yang ada yaitu seperti jumlahnya yang terbatas (bahkan cenderung langka) juga harganya yang semakin mahal dan tidak ekonomis. Salah satu cara untuk mengatasi masalah tersebut adalah melalui upaya pengawetan kayu. Pengawetan kayu dengan bahan pengawet sintetis cenderung membahayakan baik lingkungan maupun bagi manusia. Hal ini mendorong usaha untuk mencari bahan pengawet yang tidak membahayakan, dimana salah satu diantaranya adalah dengan memanfaatkan bahan pengawet alami yang bersifat aman bagi lingkungan (biodegradable) dan bersifat terbaharui (renewable).

Keawetan kayu secara alami salah satunya ditentukan oleh peranan zat ekstraktif yang bersifat racun terhadap organisme perusak kayu. Sjostrom (1998), menyatakan senyawa fenolik yang terdapat pada kayu teras dan juga kulit, bersifat racun atau antijamur. Sejumlah penelitian telah dilakukan untuk membuktikan keampuhan ekstraktif kulit kayu sebagai penghambat aktivitas antijamur. Penelitian Marzuki et al. (2018) telah menyimpulkan bahwa ekstrak kulit batang Banyuru (Pterosperum celebicum Miq) bisa menghambat beberapa pertumbuhan jamur. Selain itu Pradana et al. (2014) menyimpulkan bahwa ekstrak kulit Rhizophora mucronata dapat menghambat pertumbuhan jamur dan bakteri. Soleman dan Setiawan (2017) telah menyimpulkan bahwa kulit batang jambu mete (Anacardium occidentale L) memiliki aktivitas antijamur. Menurut Haygreen dan Bowyer (1989) kandungan ekstraktif dalam kulit batang kayu lebih tinggi daripada dalam kayu. Oleh karena itu tidak menutup kemungkinan penggunaan kulit kayu jati (Tectona grandis Linn f) berpotensi sebagai pengawet kayu yang diharapkan 
mampu menghambat pertumbuhan jamur S. commune. Tujuan dari penelitian adalah untuk menguji aktivitas antijamur secara in-vitro dan mendapatkan konsentrasi terbaik dari ekstrak kulit jati (T. grandis Linn f) dalam menghambat pertumbuhan jamur S. commune Fries.

\section{METODE PENELITIAN}

\section{Tempat dan Waktu Penelitian}

Penelitian dilaksanakan di Laboratorium Teknologi Kayu dan Wood Workshop Fakultas Kehutanan Universitas Tanjungpura Pontianak dan Laboratorium Kimia Fakultas Matematika dan Ilmu Pengetahuan Alam Universitas Tanjungpura Pontianak. Penelitian dilaksanakan selama \pm 4 bulan mulai dari persiapan sampai pengujian dan pengolahan data.

\section{Alat dan Bahan}

Alat yang digunakan dalam penelitian adalah hammer mill, meshscreen ukuran 40-60 mesh, Erlenmeyer, beaker glass, mortar, desikator, hot plate, magnetic stirrer, sprayer berisi alkohol, kertas saring meteran, autovlace, laminar air flow, lemari inkubasi, cawan petri, jarum ose, alumunium foil, vortex mixer, Bunsen, plastic warp, caliper, jangka sorong, silica $\mathrm{GF}_{254}$, pipa kapiler (pentotol), UV $366 \mathrm{~nm}$, timbangan analitik dan botol vial. Bahan yang digunakan adalah limbah kulit jati yang diambil dari di BKPH Ledok Kecamatan Sambong, KPH Cepu Perum Perhutani di Kabupaten Blora, Provinsi Jawa Tengah, kultur murni $S$. commune yang diperoleh dari Laboratorium Teknologi
Kayu Fakultas Kehutanan Universitas Tanjungpura, Aquades, Antibiotik chloramphenicol, serbuk PDA instant (Merck, Germany), bahan kimia Dietil Eter, H2SO4, Larutan LiebermannBuchard, Serbuk Magnesium, HCL, $\mathrm{NaOH} 10 \%, \mathrm{FeCl} 31 \%$, pereaksi Meyer, Dragrendorf, dan Wagner).

\section{Persiapan Sampel}

Kulit jati diperoleh dari pohon jati yang sudah diteres terletak di BKPH Ledok Kecamatan Sambong, Kabupaten Blora, Provinsi Jawa Tengah. Kulit jati bagian luar yang sangat kasar atau beralur dibuang. Bagian kulit dalam yang bersih yang diambil. Kulit jati yang telah bersih kemudian dipotong menjadi bagian kecil dijemur dan dikeringkan pada suhu kamar $25-30^{\circ} \mathrm{C}$ selama 7 hari. Selanjutnya kulit jati dibuat serbuk dengan alat Hammer mill. Serbuk disaring dengan saringan lolos 40 mesh tertahan 60 mesh. Selanjutnya dilakukan pengujian kadar air dengan mengoven sebanyak 2 gram serbuk pada suhu $103 \pm 2^{\circ} \mathrm{C}$ sampai mencapai berat konstan (Manuhuwa, 2007). Penentuan kadar air dihitung berdasarkan rumus:

$$
\mathrm{KA}=\mathrm{BA}-\frac{\mathrm{BKT} \times 100 \%}{\mathrm{BKT}}
$$

dimana :

$$
\begin{aligned}
& \mathrm{KA}=\text { Kadar air }(\%) \\
& \mathrm{BA}=\text { Berat serbuk awal (gram) } \\
& \mathrm{BKT}=\text { Berat kering tanur (gram) } \\
& \text { Perhitungan Rendemen }
\end{aligned}
$$

Serbuk kulit jati ditimbang sebanyak 1 gram, selanjutnya serbuk kulit jati direbus dengan pelarut 
aquades, dengan perbandingan 1:20. Setelah itu, disaring dengan menggunakan kertas saring meteran. Filtrat hasil penyaringan selanjutnya dimasukkan ke dalam cawan kosong yang telah ditimbang beratnya, filtrat tersebut kemudian dipanaskan di waterbath agar pelarut air menguap. Residu kembali dimaserasi seperti perlakuan awal sampai didapat filtrat yang jernih. Selanjutnya cawan yang berisi ekstrak kasar kulit jati hasil dari pemanasan di waterbath di oven dengan suhu $60^{\circ} \mathrm{C}$ selama 15 menit, kemudian dikeluarkan dari oven dan dimasukkan ke dalam desikator untuk menstabilkan suhunya. Setelah itu ditimbang dan dihitung rendemennya.

Rendemen ekstrak dihitung dengan menggunakan rumus (Rahmah et al. 2012) :

Rendemen ekstrak :

$\frac{\text { bobot ekstrak }}{\text { bobot serbuk (1- kadar air) }} \times 100 \%$

Proses Ekstraksi

Proses ekstraksi dilakukan merebus kulit jati sebanyak $1 \mathrm{~kg}$ dengan pelarut aquades sebanyak 10 liter. Campuran diaduk dengan menggunakan batang pengaduk, kemudian direbus selama 3 jam (Lukmandaru, 2009). Larutan hasil ekstraksi disaring menggunakan kertas saring meteran untuk memisahkan residu dengan larutan ekstrak dan dikeringkan dengan menggunakan oven bersuhu $60^{\circ} \mathrm{C}$ sampai diperoleh ekstrak murni dari kulit jati.

\section{Skrining Fitokimia}

Pengujian fitokimia ekstrak kulit jati dilakukan mengikuti prosedur Harborne (1996) yang dimodifikasi.
Sebanyak 1 gram ekstrak kulit jati dimasukan kedalam tabung reaksi, kemudian diencerkan dengan pelarut air sebanyak $\pm 10 \mathrm{~mL}$ (Mailuhu et al. 2017).

\section{Uji Alkaloid}

Sebanyak $1 \mathrm{~mL}$ ekstrak kulit jati dimasukan ke dalam 3 tabung reaksi. Setelah itu, masing-masing tabung ditambahkan 10 tetes $\mathrm{H}_{2} \mathrm{SO}_{4} 2 \mathrm{~N}$ dan dikocok kuat. Pada tabung pertama ditambahkan pereaksi Dragendorff, pada tabung yang kedua ditambahkan pereaksi Wagner, dan pada tabung yang ketiga ditambahkan pereaksi Meyer. Apabila terbentuk endapan menunjukkan bahwa ekstrak tersebut mengandung alkaloid. Hasil positif bila dengan pereaksi Dragendorff menghasilkan endapan berwarna merah jingga, dengan pereaksi Wagner menghasilkan endapan berwarna coklat, dan dengan perekasi Meyer menghasilkan endapan berwarna putih (Mailuhu et al. 2017).

\section{Uji Flavonoid}

Sebanyak $1 \mathrm{~mL}$ ekstrak kulit jati dimasukan ke dalam tabung reaksi, kemudian ditambahkan $\mathrm{HCl}$ pekat sebanyak 2 tetes dan dikocok kuat. Setelah itu, ditambahkan serbuk magnesium (Mg) dan dikocok kuat. Hasil positif ekstrak mengandung flavonoid apabila terdapat buih dengan intensitas yang banyak dan larutan menghasilkan warna jingga (Mailuhu et al. 2017).

\section{Uji Terpenoid dan Steroid}

Sebanyak $1 \mathrm{~mL}$ ekstrak jati dimasukan ke dalam 2 tabung reaksi. 
Lalu dimasukan masing-masing tabung dengan larutan Lieberman-Burchard, dan dietil eter sebanyak 2 tetes, kemudian diamati perubahan warnanya. Hasil positif steroid jika menghasilkan warna biru atau hijau, sedangkan terpenoid menghasilkan warna merah atau kecokelatan (Sangi et al. 2008).

\section{Uji Fenolik}

Sebanyak $1 \mathrm{~mL}$ ekstrak kulit jati dimasukan ke dalam tabung reaksi lalu ditambahkan 2-3 tetes $\mathrm{FeCl}_{3} 1 \%$. Hasil positif mengandung fenol apabila menghasilkan warna biru kehitaman (Mailuhu et al. 2017).

\section{Uji Antrakuinon}

Sebanyak $1 \mathrm{~mL}$ ekstrak kulit jati dimasukan ke dalam tabung reaksi lalu ditambahkan 3 tetes $\mathrm{NaOH} 1 \mathrm{~N}$. hasil positif mengandung kuinon ditunjukkan dengan terbentuknya warna merah kecokelatan.

\section{Uji Saponin}

Diambil sebanyak $1 \mathrm{~mL}$ ekstrak jati ditambahkan dengan $5 \mathrm{~mL}$ air panas sambil dikocok kuat selama 1 menit, lalu ditambahkan 2 tetes $\mathrm{HCl} 2 \mathrm{~N}$. Bila busa yang terbentuk tetap stabil selama kurang lebih 10 menit, maka ekstrak positif mengandung saponin (Mailuhu et al. 2017).

\section{Pembuatan Media PDA (Potato} Dextrose Agar)

Pembuatan media PDA menggunakan serbuk PDA instan sebanyak 39 gram kemudian dimasukkan ke dalam beaker glass. Setelah itu ditambahkan aqudes sebanyak $1.000 \mathrm{~mL}$ dan dipindah ke
Erlenmeyer. Panaskan larutan PDA instan diatas hot plate dan diaduk dengan magnetic stirrer hingga larutan menjadi homogen. Pelarutan tidak dilakukan sampai mendidih dan diusahakan larutan harus sempurna sehingga tidak ada kristal yang tersisa, selanjutnya larutan disterilisasi $\pm 121^{0} \mathrm{C}$ (1 atm) selama \pm 15 menit di dalam autoclave (Merck, Germany). Setelah di autoclave tambahkan antibiotik chloramphenicol dan larutan dihomogenkan kembali dengan bantuan pemanasan $\left(\leq 70^{0}\right.$ C) (Basarang dan Rianto, 2018).

Perbanyakan Jamur Schizophyllum commune Fries

Isolat jamur $S$. commune Fries diperoleh dari Laboratorium Teknologi Kayu Fakultas Kehutanan Universitas Tanjungpura Pontianak. Jamur dibiakkan pada media PDA dan diinkubasi selama tujuh hari pada suhu kamar, setelah tujuh hari jamur $S$. commune yang tumbuh dimurnikan dengan cara yang sama sampai memperoleh biakan murni yang tidak terkontaminasi oleh bakteri atau jamur lainnya (Khan dan Zhihui, 2010).

\section{Pembuatan Konsentrasi}

Konsentrasi ekstrak yang digunakan meliputi 0,25\%, 0,5\%, $0,75 \%$, dan $1 \%$. Pembuatan konsentrasi ekstrak $1 \%$ ditambahkan 0,01 gram ekstrak jati (sebelumnya ekstrak kulit jati 0,01 gram dilarutkan dengan $1 \mathrm{ml}$ aquades) dengan $8,9 \mathrm{ml}$ PDA. Pembuatan konsentrasi disajikan pada Tabel 1. 
Tabel 1. Pembuatan konsentrasi ekstrak kulit jati (Concentration of teak bark extract)

\begin{tabular}{ccccc}
\hline Konsentrasi & Ekstrak & Aquadest & PDA & Total \\
\hline $0,25 \%$ & $0,025 \mathrm{~g}$ & $1 \mathrm{ml}$ & $8,9 \mathrm{ml}$ & $10 \mathrm{ml}$ \\
$0,50 \%$ & $0,050 \mathrm{~g}$ & $1 \mathrm{ml}$ & $8,9 \mathrm{ml}$ & $10 \mathrm{ml}$ \\
$0,75 \%$ & $0,075 \mathrm{~g}$ & $1 \mathrm{ml}$ & $8,9 \mathrm{ml}$ & $10 \mathrm{ml}$ \\
$1,00 \%$ & $0,100 \mathrm{~g}$ & $1 \mathrm{ml}$ & $8,9 \mathrm{ml}$ & $10 \mathrm{ml}$ \\
\hline
\end{tabular}

Pengujian Aktivitas AntiJamur

Pengujian aktivitas antijamur dilakukan dengan menggunakan metode penghambatan pertumbuhan radial miselium (Khan dan Zhihui, 2010), yaitu dengan mencampur media PDA dengan ekstrak kulit jati. Biakan jamur ditanam langsung ditengah-tengah cawan petri. Perhitungan persentase penghambatan diambil dari hasil pengukuran diameter koloni dari hari ke-1 sampai hari ke-7 setelah inokulasi. Pengukuran pertumbuhan jamur pada media kontrol $(0 \%)$ digunakan untuk menghitung besarnya persentase penghambatan dari setiap tingkat konsentrasi ekstrak kulit jati terhadap pertumbuhan jamur $S$. commune. Presentase aktivitas antijamur ekstrak kulit jati terhadap pertumbuhan jamur $S$. commune dihitung dengan menggunakan rumus Khan dan Zhihui (2010) sebagai berikut:

$\mathrm{AFA}=\frac{\mathrm{GC}-\mathrm{GT}}{\mathrm{GC}} \times 100 \%$

Keterangan:

AFA = Presentase penghambatan

/Aktivitas Antijamur (\%)

$\mathrm{GC}=$ Diameter koloni jamur kontrol (mm)

GT = Diameter koloni jamur dalam media berekstrak (mm)

\section{Analisis Data}

Penelitian menggunakan

Rancangan Acak Lengkap (RAL) dengan 5 perlakuan dan 3 kali ulangan. Perlakuan yang diberikan adalah tingkat konsentrasi ekstrak kulit jati. Adapun tingkat konsentrasi ekstrak kulit jati yang menjadi perlakuan adalah konsentrasi $0 \%, 0,25 \%, 0,5 \%, 0,75 \%$, dan $1 \%$.

\section{HASIL DAN PEMBAHASAN}

\section{Kadar Ekstraktif Kulit Jati}

Penelitian ini menggunakan metode ekstraksi dengan air panas. Ekstrak kulit jati yang diperoleh berwarna coklat pekat dengan rendemen sebesar $6,46 \%$ dan kadar air sebesar 9,53\%. Rendemen ekstrak kulit jati yang diperoleh relatif lebih tinggi dibanding dengan penelitian Puteri (2012) yang melakukan ekstraksi kulit jati dengan pelarut etanol:toulena (1:1) yang memiliki rendemen ekstrak sebesar $5,69 \%$. Perbedaan pelarut yang digunakan sangat mempengaruhi rendemen ekstrak yang dihasilkan. Fengel dan Wegener (1995) secara lebih jelas mengatakan bahwa metode ekstraksi merupakan faktor yang menyebabkan variasi pada kandungan dan komposisi zat ekstraktif.

Berdasarkan klasifikasi komponen kimia kayu Indonesia, suatu bahan tergolong memiliki kadar ekstraktif yang tinggi jika kadar zat ekstraktif lebih besar dari 4\%. Kemudian termasuk kelas sedang dengan ekstraktif 2-4\% dan kelas rendah kurang dari 2\% (Dirjen Kehutanan, 1976). Berdasarkan 
klasifikasi tersebut kadar ekstraktif kulit jati yang diperoleh tergolong ke dalam kelas tinggi karena kadarnya lebih besar dari $4 \%$.

\section{Skrining Fitokimia}

Skrining fitokimia dilakukan untuk memastikan keberadaan senyawa metabolit sekunder seperti alkaloid, flavonoid, fenolik dan senyawasenyawa lain yang berpotensi dalam menghambat pertumbuhan jamur $S$. commune Fries. Skrining fitokimia dilakukan secara kualitatif untuk menganalisa keberadaan senyawa seperti alkaloid, flavonoid, tanin, terpenoid, fenolik, antrakuinon, dan saponin. Berdasarkan hasil skrining fitokimia yang telah dilakukan maka diketahui bahwa ekstrak kulit jati positif mengandung senyawa alkaloid, flavonoid, terpenoid, antrakuinon, fenolik, dan antrakuinon. Akan tetapi tidak ditemukan senyawa steroid pada ekstrak tersebut. Selengkapnya hasil skrining fitokimia tersaji pada Tabel 2

Tabel 2. Hasil skrining fitokimia ekstrak kulit Jati (Phytochemical screening tests of teak bark extract)

\begin{tabular}{cccc}
\hline Uji Fitokimia & Pereaksi & Hasil & Kesimpulan \\
\hline & Mayer & Terbentuk endapan putih & $(+)$ \\
Alkaloid & Wagner & Terbentuk warna cokelat kekuningan & $(+)$ \\
& Dragendroff & Terbentuk warna jingga & $(+)$ \\
Flavonoid & $\mathrm{Mg}+\mathrm{HCl}$ & Terbentuk warna jingga & $(+)$ \\
Terpenoid & Liebermann-burchard & Terbentuk warna cokelat kemerahan & $(+)$ \\
Steroid & Liebermann-burchard & Tidak terbentuk warna hijau & $(-)$ \\
Saponin & $\mathrm{Air}+\mathrm{HCl}$ & Terbentuk busa stabil & $(+)$ \\
Tanin/Fenolik & $\mathrm{FeCl}_{3} 1 \%$ & Terbentuk warna hijau kehitaman & $(+)$ \\
Antrakuinon & $\mathrm{NaOH} \mathrm{1} \mathrm{N}$ & Terbentuk warna merah & $(+)$ \\
\hline
\end{tabular}

Keterangan : (+) = Ada; $(-)$ = Tidak ada

Penghambatan Pertumbuhan Jamur Schizophyllum commune Fries

Pengukuran diameter dilakukan selama 9 (sembilan) hari karena jamur S. commune pada media kontrol telah penuh (Wijayanto, 2015). Rerata pertumbuhan jamur $S$. commune untuk kontrol (0\%) pada hari ke-9 yaitu sebesar $90 \mathrm{~mm}$ dan sudah memenuhi cawan petri. Konsentrasi $0,25 \%$ rerata pertumbuhan jamur sebesar $64,82 \mathrm{~mm}$, konsentrasi $0,5 \%$ rerata pertumbuhan jamur sebesar 53,66 mm, konsentrasi $0,75 \%$ rerata pertumbuhan jamur sebesar 36,06 mm, dan konsentrasi $1 \%$ rerata pertumbuhan jamur sebesar 31,04 mm. Adapun pertumbuhan jamur $S$. commune setelah 9 hari pada media dengan konsentrasi ekstrak kulit jati dapat dilihat pada Gambar 1. 


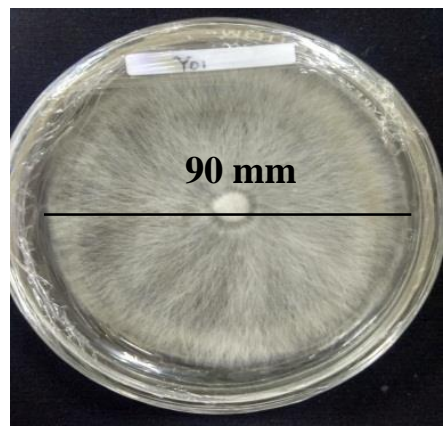

a

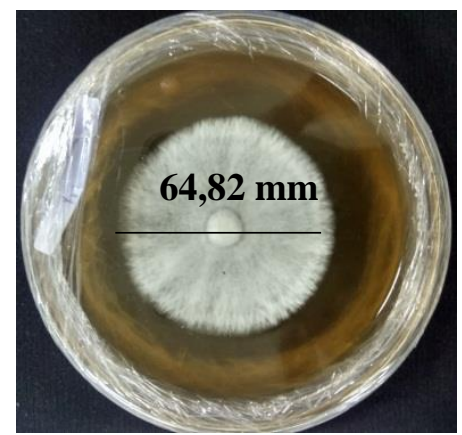

b

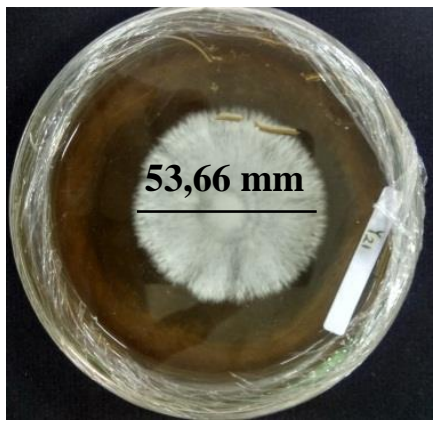

C

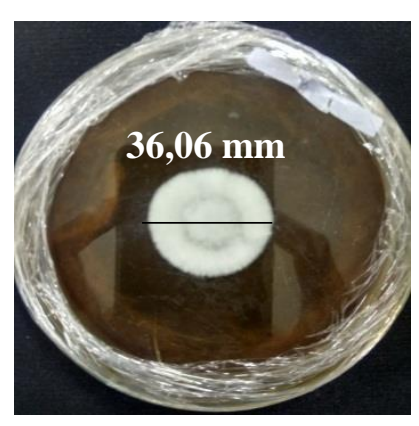

$\mathrm{d}$

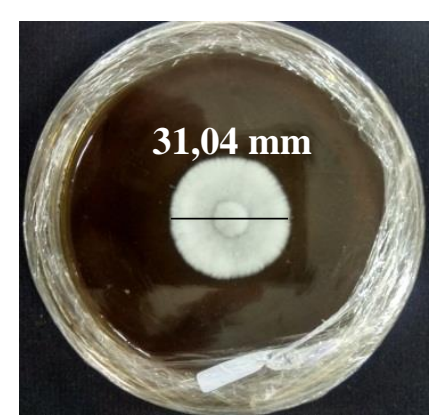

e

Gambar 1. Pertumbuhan jamur S. commune setelah 9 hari pada media Potatoes Dextrose Agar dengan konsentrasi ekstrak kulit Jati yang berbeda: a. kontrol $0 \%$; b. konsentrasi $0,25 \%$; c. konsentrasi $0,5 \%$; d. konsentrasi $0,75 \%$; e. konsentrasi 1\% (The growth of S. commune fungi after 9 days at Potatoes Dextrose Agar medium with different concentration of teak bark extract: a. control $0 \% ; b$. concentration $0,25 \% c$. concentration $0,5 \%$; $d$. concentration $0,75 \%$; e. concentration $1 \%$ )

\section{Aktivitas Antijamur Ekstrak Kulit Jati (Tectona grandis Linn F)}

Nilai rerata aktivitas antijamur $S$. commune dari ekstrak kulit jati berkisar dari $27,98 \%$ pada konsentrasi $0,25 \%$ sampai $65,51 \%$ pada konsentrasi $1 \%$. Pengamatan aktivitas antijamur dihentikan saat miselium jamur pada kontrol (tanpa perlakuan ekstrak) memenuhi cawan petri yaitu pada hari ke 9 (Wijayanto, 2015). Rerata aktivitas antijamur (AFA) ekstrak kulit jati terhadap koloni jamur berdasarkan taraf konsentrasi disajikan pada Tabel 3. 
Tabel 3. Rerata persentase aktivitas antijamur (AFA) berdasarkan taraf konsentrasi ekstrak kulit Jati $T$. grandis terhadap koloni jamur $S$. commune (The average of percentage of antifungal activity based on concentration of extract of teak bark $T$. grandis against colony of $S$. commune fungi)

\begin{tabular}{ccc}
\hline Konsentrasi $(\boldsymbol{\%})$ & Rerata AFA $(\boldsymbol{\%})$ & Tingkat Aktivitas \\
\hline 0 & 0 & Tidak aktif \\
0,25 & 27,98 & Sedang \\
0,50 & 40,38 & Sedang \\
0,75 & 59,94 & Kuat \\
1 & 65,51 & Kuat \\
\hline
\end{tabular}

Sumber Mori et al. (1997)

Berdasarkan klasifikasi Mori et al (1997), hasil penelitian menunjukan bahwa pada taraf konsentrasi $0 \%$ tingkat aktivitas antijamur tidak aktif, pada taraf $0,25 \%$ dan $0,50 \%$ tingkat aktivitas antijamur sedang, dan pada taraf $0,75 \%$ dan $1 \%$ tingkat aktivitas antijamur kuat. Pemberian konsentrasi ekstrak kulit jati dapat menghambat pertumbuhan miselia jamur $S$. commune. Semakin besar konsentrasi yang diberikan pada media pertumbuhan, semakin besar nilai antijamur yang dihasilkan. Peningkatan konsentrasi ekstrak akan meningkatkan persentase penghambatan pertumbuhan jamur. Pengaruh pemberian ekstrak kulit jati (T. grandis) terhadap pertumbuhan jamur $S$. commune disajikan pada Gambar 2.

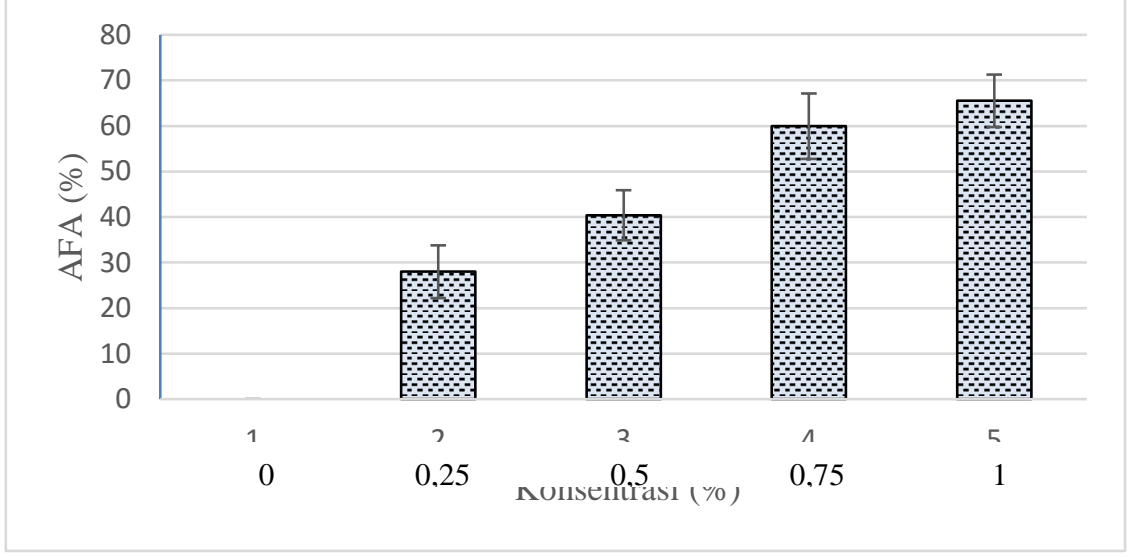

Gambar 2. Nilai rerata aktivitas antijamur ekstrak kulit Jati (T. grandis) terhadap pertumbuhan jamur $S$. commune setelah 9 hari inkubasi (The average values of antifungal activity of teak bark extract (T. grandis) against the growth of S. commune fungi after 9 days incubation)

Gambar 2 menunjukkan konsentrasi $1 \%$ memberikan aktivitas antijamur paling tinggi yaitu sebesar $65,51 \%$. Sementara pada konsentrasi ekstrak $0,25 \%, 0,50 \%$ dan $0,75 \%$ nilai aktivitas antijamur jamur berturut- turut adalah $27,98 \%, 40,38 \%$, dan 59,94\%. Ekstrak kulit jati yang diberikan pada media PDA memiliki aktivitas antijamur terhadap pertumbuhan jamur $S$. commune Fries. Berdasarkan Uji senyawa metobolit sekunder dengan skrining fitokimia, kulit jati yang 
digunakan mengandung senyawa diantaranya adalah alkaloid, flavonoid, terpenoid, saponin, dan kuinon yang bersifat antijamur.

Senyawa yang terkandung di dalam ekstrak kulit jati yang aktif sebagai antijamur dapat bekerja melalui salah satu dari cara berikut ini. Alkaloid mempunyai aktivitas antijamur dengan cara mengganggu komponen penyusun peptidoglikon pada sel jamur sehingga lapisan dinding sel tidak terbentuk secara utuh dan menyebabkan kematian sel tersebut (Nuryanti et al. 2016). Flavonoid dapat bertindak sebagai antijamur karena mempunyai senyawa fenol yang dapat mendenaturasi protein dan dapat merusak membran sel yang bersifat irreversible (tidak dapat diperbaiki lagi). Mekanisme kerja flavonoid dalam menghambat jamur bekerja dengan cara denaturasi protein sehingga meningkatkan permeabilitas membran sel. Denaturasi protein menyebabkan gangguan dalam pembentukan sel sehingga merubah komponen protein, dengan terganggunya membran sel dapat menyebabkan meningkatnya permeabilitas sel sehingga menyebabkan kerusakan sel jamur. Kerusakan tersebut dapat menyebabkan kematian sel jamur (Wahyuningtyas, 2008). Saponin diketahuin mempunyai tingkat toksisitas yang tinggi dalam menghambat jamur. Mekanisme kerja saponin sebagai antijamur berhubungan dengan interaksi saponin dengan sterol membran. (Huslina, 2017).

Berdasarkan hasil penelitian yang telah dilakukan, uji daya hambat ekstrak kulit jati terhadap pertumbuhan jamur $S$. commune menunjukan konsentrasi $0,75 \%$ memberikan nilai aktivitas antijamur 59,94\% dan konsentrasi $1 \%$ memberikan nilai aktivitas antijamur 65,51\%. Kemudian hasil uji BNJ menunjukan konsentrasi $0,75 \%$ dan $1 \%$ tidak berbeda nyata. Oleh karena itu konsentrasi yang terbaik dari ekstrak kulit jati untuk menghambat pertumbuhan jamur $S$. commune adalah $0,75 \%$ dan $1 \%$. Ekstrak kulit jati berpotensi sebagai bahan pengawet alami.

\section{KESIMPULAN}

Berdasarkan hasil penelitian yang telah dilakukan dapat disimpulkan bahwa :

1. Kadar air ekstrak kulit jati T. grandis Linn $F$ sebesar 9,53\% dengan rendemen sebesar $6,46 \%$.

2. Kandungan metabolit sekunder ekstrak kulit jati yaitu alkaloid, flavonoid, terpenoid, fenolik, antrakuinon dan saponin.

3. Ekstrak kulit jati berpotensi sebagai bahan pengawet alami terhadap serangan jamur S. commune. Semakin tinggi konsentrasi ekstrak kulit jati maka daya hambat terhadap jamur semakin kuat.

4. Nilai aktivitas antijamur S. commune dari ekstrak kulit jati berkisar dari $27.98 \%$ pada konsentrasi $0,25 \%$ sampai $65,51 \%$ pada konsentrasi $1 \%$.

5. Konsentrasi $0,75 \%$ dan $1 \%$ ekstrak kulit jati memberikan konsentrasi terbaik dalam menghambat pertumbuhan jamur S. commune.

\section{SARAN}

Perlu dilakukan penelitian lanjutan untuk uji daya hambat ekstrak kulit jati yang diujikan langsung ke kayu dan melakukan pengujian lebih lanjut dengan metode ekstraksi atau bahan pelarut yang berbeda dan diuji ke organisme perusak kayu lainnya.

\section{Daftar Pustaka}

Barly. 2012. Pengawetan Kayu: Solusi terbaik memecahkan masalah. Forpro 1(2): 22-24.

Barly, dan Sabarudi. 2010. Kajian industri dan kebijakan pengawetan kayu sebagai upaya 
mengurangi tekanan terhadap hutan. Jurnal Analisis Kebijakan Kehutanan 7(1): 63-80.

Basarang, dan Rianto. 2018. Pertumbuhan Candida sp dan Aspergillus sp dari Bilasan Bronkus Penderita Tuberkulosis Paru pada Media Bekatul. Jurnal Ilmu Alam dan Lingkungan 9(18): 74-82.

Batubara R, Rosamah E, dan Budiarso E. 2008. Identifikasi Sifat Ekstrak Kulit Kayu Medang Hitam (Cinnamomum porrectum Roxb) Sebagai Bahan Pengawet Kayu. Jurnal Kehutanan Tropika Humida 1(1): 74-83.

Dhingra OD, dan Sinclair JB. 1985. Basic Plant Pathology Methods, Florida: CRC Press.

Direktorat Jendral Kehutanan. 1976. Vademecum Kehutanan Indonesia. Jakarta: Direktorat Jendral Kehutanan.

Fengel D, dan Wegener G. 1995. Kayu: Kimia, Ultrastruktur, Reaksireaksi. Sastrahamidjoyo $\mathrm{H}$, penerjemah. Wood: Chemistry, Ultrastructure, Reactions. Yogyakarta.: Gadjah Mada University Press.

Harbone IB. 1987. Metode Fitokimia. Bandung: Penerbit ITB.

Harun J, dan Labosky P. 1985. Antitermitic and Antifungal Properties of Selected Bark Extractives. Wood and Fiber Science 17(3): 327-335.

Haygreen JG, dan Bowyer. 1989. Hasil Hutan dan Ilmu Кауи: Suatu Pengantar. Hadikusumo SA, penerjemah. Forest Products and Wood Science: an Introduction.
Yogyakarta: Gajah Mada University Press.

Herliyana EN, Mariyam LF, dan Hadi YS. 2011. Schizophyllum commune Fr. sebagai jamur uji ketahanan kayu standar nasional Indonesia pada Empat jenis kayu rakyat: sengon ( $P$. falcataria), karet (H. brasiliensis), tusam ( $P$. merkusii), mangium (A. mangium). Jurnal Silvikultur Tropika 2(3):176-180.

Huslina F. 2017. Pengaruh Ekstrak Daun Lidah Buaya (Aloe vera $\mathrm{L}$ ) Terhadap Pertumbuhan Jamur Candida albicans Secara In Vitro. Jurnal Biotik. 5(1): 72-77.

Khan MA, dan Zhihui C. 2010. Influence of garlic root exudates on cyto-morphological alteration of the hyphae of phytophthora capsici, the cause of phytophthora blight in pepper. Journal Botanical 42(6):4353-4361.

Lukmandaru G. 2009. Pengukuran Kadar Ekstraktif dan Sifat Warna Pada Kayu Teras Jati Doreng (Tectona grandis). Jurnal Ilmu Kehutanan. 3(2): 67-73.

Mailuhu M, Runtuwene MRJ, dan Koleangan HSJ. 2017. Skrining Fitokimia dan Aktivitas Antiosidan Ekstrak Metanol Kulit Batang Soyogik (Saurauia bracteosa DC). Chemistry Progress. 10(1): 1-7.

Manuhuwa E. 2007. Kadar Air dan Berat Jenis Pada Posisi Aksial dan Radial Kayu Sukun ) Arthocarpus communis, J.R dan G.Frest). Jurnal Argoforestri. 2(1).

Marzuki A, Djide MN, Sartika, dan Rosany T. 2018. Aktivitas Ekstrak 
Kulit Batang Banyuru (Pterospermum celebicum Miq) dan Ekstrak Lengkuas (Alpinia galanga L Willd) Sebagai Antifungi Terhadap Trichophyton rubrum, Candida albicans, dan Aspergillus niger. Jurnal Ilmiah Farmasi 7(3): 354-362.

Mori M, Aoyama M, Doi S, Kanetoshi A, dan Hayashi T. 1997. Antifungal Activity of Bark Extracts of Deciduos Trees. Holz als Roh- Und Wekstoof 55: 130132.

Nuryanti S, Mustapa K, dan Sudarmo IG. 2016. Uji Daya Hambat Ekstrak Buah Kelor (Moringa oleifera Lamk) Terhadap Pertumbuhan Jamur Candida albicans. J. Akad. Kim 5(4): 178184.

Oramahi HA, Diba F, Tavita GE, dan Wahyuni R. 2012. Penggunaan Asap Cair Dari Tandan Kosong Kelapa Sawit (TKKS) Dalam Penekanan Perkembangan Jamur Schizophyllum commune. Jurnal Tengkawang 1(2): 51-56.

Pradana D, Suryanto D, dan Yunasfi. 2014. Uji Daya Hambat Ekstrak Kulit Batang Rhizophora mucronata Terhadap Pertumbuhan Bakteri Aeromonas hydrophila, Streptococus agalactiae dan Jamur Saprolegnia sp. Secara In Vitro. Jurnal Aquacoastmarine 2(1): 78-92.

Puteri AYP. 2012. Kadar Tektokuinon pada Ekstrak Kayu dan Kulit Jati (Tectona grandis L.f) Jawa Barat dan Jawa Timur. Bogor: Institut Pertanian Bogor.

Rahmah SA, Suharti, dan Subandi. 2012. Uji Antibakteri dan Daya
Inhibisi Ekstrak Kulit Manggis (Garcinia mangostana L.) Terhadap Aktivitas Xantin Aksidase yang Diisolasi dari Air Susu Sapi Segar. Jurnal Online Kimia Universitas Malang 1(1).

Rinaldi MG. 1982. Use of Potato Flakes Agar in Clinical Mycology. Journal of Clinical Microbiology. 15(6): 1159-1160.

Sangi M, Runtuwene MRJ, Simbala HEI, dan Makang VMA. 2008. Analisis Fitokiia Tumbuhan Obat di Kabupaten Minahasa Utara. Chemistry Progress 1(1): 47-53.

Sjostrom. 1998. Kimia Kayu: Dasardasar Penggunaan Edisi ke-2. Sastrohamidjojo H, penerjemah. Wood Chemistry, Fundamentals and Applications. Yogyakarta: Gadjah Mada University Press.

Soleman D, dan Setiawan NCE. 2017. Aktivitas Antifungi Ekstrak Metanol Kulit Batang Jambu Mete Terhadap Candida albicans. Journal Cis-Trans 1(2): 25-29.

Standar Nasional Indonesia. 2006. SNI 01-7207-2006 tentang Uji Ketahanan dan Produk Kayu Terhadap Organisme Perusak Kayu.

Wahyuningtyas E. 2008. Pengaruh Ekstrak Graptophyllum picttum Terhadap Pertumbuhan Candida albicans Pada Plat Gigi Tiruan Resin Akrilik. Journal of Dentistry. 15(3): 187-191.

Wijayanto A. 2015. Aktivitas Antijamur dan Antioksidan Ekstrak Kayu Jati dan Tusam Bogor. Institut Pertanian Bogor. 